\title{
Preparation and characterization of $\mathrm{LaNiO}_{3}$ films grown by metal-organic deposition
}

\author{
YAO WANG, GUOFANG ZHANG*, CHENGSHAN LI ${ }^{\dagger}$, GUO YAN ${ }^{\dagger}$ and YAFENG LU \\ Key Laboratory of Applied Surface and Colloid Chemistry (Shaanxi Normal University), Ministry of Education, \\ Xi'an 710062, P.R. China; School of Chemistry and Chemical Engineering, Shaanxi Normal University, \\ Xi' an 710062, P.R. China \\ ${ }^{\dagger}$ Northwest Institute for Nonferrous Metal Research, Xi’an 710016, P.R. China
}

MS received 3 March 2009

\begin{abstract}
We have investigated the synthesis and characterization of $\mathrm{LaNiO}_{3}$ (LNO) layers deposited on YSZ (100) substrate by metal-organic deposition (MOD). Texture, morphology and electrical properties of the $\mathrm{LaNiO}_{3}$ films were characterized by $\mathrm{X}$-ray diffraction (XRD), atomic force microscopy (AFM), scanning electron microscopy (SEM) and electrical resistivity measurement. It has been found that the formation of (h00) orientation depends on pyrolysis temperature, annealing temperature and thickness of $\mathrm{LaNiO}_{3}$ layers. The $\mathrm{LaNiO}_{3}$ films prepared under optimal condition indicate highly (h00) orientation and a rather smooth surface. The $\mathrm{LaNiO}_{3}$ films show a metallic behaviour in the measured temperature range.
\end{abstract}

Keywords. Conductive films; $\mathrm{LaNiO}_{3}$; metal-organic deposition; texture.

\section{Introduction}

In recent decades, high-temperature superconducting coated conductors based on $\mathrm{YBa}_{2} \mathrm{Cu}_{3} \mathrm{O}_{7-\delta}(\mathrm{YBCO})$ have attracted great interest for electric power application (Larbalestier et al 2001). The orientation and microstructure of buffer layers between substrate and superconducting layer are very critical to the textured growth and the superconducting performance of YBCO layers. Preparation of buffer layers with high quality, therefore, becomes rather important in order to transfer the texture from substrate into YBCO layer and to realize chemical barriers between the metal substrate and superconducting layer. The considerations for candidates of buffer layers usually include lattice matching, structural and chemical compatibility with the metal substrate and YBCO (Knoth et al 2007). A number of electrical insulating buffer layers have been tested so far, but conductive buffer layers have huge commercial prospects because of their potential engineering applications for superconductors. Among many conductive buffer layers, $\mathrm{LaNiO}_{3}$ (LNO) has been proved to be a good candidate because it exhibits perovskite structure with a lattice parameter $(a=0.384 \mathrm{~nm})$ close to that of YBCO and high conductivity over a wide temperature range (Lee et al 1993; Bhuiyan et al 2006).

During past years, many kinds of deposition methods, such as pulsed laser deposition (PLD) (Sanchez et al

\footnotetext{
*Author for correspondence (gfzhang@snnu.edu.cn)
}

2000; Berini et al 2007), sputtering (Wakiya et al 2002), mist plasma evaporation (MPE) (Huang et al 2004), solgel process (Miyake et al 2002; Yu et al 2004) and chemical solution deposition (CSD) (Li et al 1996; Meng et al 2000; Zhang et al 2000; Bao et al 2003; Escote et al 2003; Miyazaki et al 2004), have been employed for preparation of $\mathrm{LaNiO}_{3}$ films on several kinds of substrates especially for electrode materials in microelectric devices. Among these deposition routes, chemical solution deposition is simpler and enables easier control over the stoichiometry of the final product than the physical methods. The MOD method has a number of advantages in comparison with other deposition methods and has extensively been used for the preparation of a variety of buffer layers in high-temperature superconducting YBCO-based coated conductors. In order to develop a kind of electrode in ferroelectric substrates, polycrystalline MOD- $\mathrm{LaNiO}_{3}$ films on Si (111) and quartz substrates were first prepared with the 2-ethyl hexanotes of lanthanum and nickel dissolved in xylene, where the lowest annealing temperature for crystallization is about $530^{\circ} \mathrm{C}$ ( $\mathrm{Li}$ et al 1996). If the appropriate thermal processing was chosen for the $\mathrm{LaNiO}_{3}$ films on the $\mathrm{SiO}_{2}$ glass substrates, the strong (100) orientation of LNO films could be obtained (Miyake et al 2002). Meanwhile, epitaxial $\mathrm{LaNiO}_{3}$ films on single crystalline substrates including $\mathrm{SrTiO}_{3}$ and $\mathrm{LaAlO}_{3}$ were successfully prepared by the MOD method (Li et al 1996; Cho et al 1997). However, the normally used lanthanum precursor $\mathrm{La}$ (III) 2-methoxyethoxide is relatively expensive in comparison with simpler La(III) salts such 
as $\mathrm{La}(\mathrm{III})$ nitrate or $\mathrm{La}(\mathrm{III})$ acetate, and the solvent 2methoxyethanol is toxic; they are, therefore, unsuitable for large-scale preparation of NGO buffer layers.

In this study we employed the relatively cheaper $\mathrm{La}\left(\mathrm{NO}_{3}\right)_{3} \cdot 6 \mathrm{H}_{2} \mathrm{O}$ and $\mathrm{Ni}\left(\mathrm{CH}_{3} \mathrm{COO}\right)_{3} \cdot 4 \mathrm{H}_{2} \mathrm{O}$ as precursors as well as acetic acid as a solvent, and systematically studied the preparation and structure of $\mathrm{LaNiO}_{3}$ films on YSZ (100) substrate, which could serve a buffer layer for coated conductors. We found that pyrolysis temperature, annealing temperature and film thickness are key factors for obtaining the highly ( $h 00)$ orientated LNO films. The LNO films by MOD show a metallic behaviour measured by transport measurement.

\section{Experimental}

The $\mathrm{LaNiO}_{3}$ precursor solution was prepared by the method as described in $\mathrm{Yu}$ et al (2004). Lanthanum nitrate $\left[\mathrm{La}\left(\mathrm{NO}_{3}\right)_{3} \cdot 6 \mathrm{H}_{2} \mathrm{O}\right]$ and nickel acetate $[\mathrm{Ni}$ $\left(\mathrm{CH}_{3} \mathrm{COO}\right)_{3} \cdot 4 \mathrm{H}_{2} \mathrm{O}$ ] (99\%; both from Alfa Aesar) were used as educts and acetic acid ( $\geq 99 \%$; Alfa Aesar) as a solvent. For preparing a precursor solution, powders of $\mathrm{La}\left(\mathrm{NO}_{3}\right)_{3} \cdot 6 \mathrm{H}_{2} \mathrm{O}$ and $\mathrm{Ni}\left(\mathrm{CH}_{3} \mathrm{COO}\right)_{3} \cdot 4 \mathrm{H}_{2} \mathrm{O}$ were mixed in stoichiometric ratio of $1: 1$, and then acetic acid was added. After heating at $70^{\circ} \mathrm{C}$ for $30 \mathrm{~min}$, a stable green solution was obtained. The concentration of the precursor solution was adjusted to $c=c_{\left(\mathrm{La}^{3+}\right)}=c_{\left(\mathrm{Ni}^{2+}\right)}=0 \cdot 3 \mathrm{M}$. Before preparation of LNO films, the powder derived from LNO gel was investigated to determine the phase formation of $\mathrm{LaNiO}_{3}$. The precursor films were deposited by spin process on YSZ (100) substrates at $3000 \mathrm{rpm}$ for $30 \mathrm{~s}$. The precursor films were heat-treated at a temperature range from $300^{\circ} \mathrm{C}$ to $450^{\circ} \mathrm{C}$ for $5 \mathrm{~h}$ to pyrolyse organic materials, and then the annealing step was carried out at various temperatures $T=500-800^{\circ} \mathrm{C}$ with $5 \mathrm{~K} \mathrm{~min}^{-1}$ heating rate for $3 \mathrm{~h}$ in air to obtain crystallized films in a horizontal furnace. After annealing the samples were cooled in the furnace down to room temperature with $2 \mathrm{~K} \mathrm{~min}^{-1}$ cooling rate. Phase and orientation of films were characterized by $2 \theta$ scans of X-ray diffraction with $\mathrm{CuK} \alpha$ radiation on a diffractometer. The surface morphology of LNO films was investigated using atomic force microscopy (AFM) and scanning electron microscopy. The temperature dependence of the electrical resistivity of these films was measured by using the standard four-probe method in a temperature range from 77 to $300 \mathrm{~K}$.

\section{Results and discussion}

In the MOD process, the selection of precursor compounds and solvents is actually important for getting high-quality films, wherein possible chemical interactions in the solution and complicated film growth mechanism during heat treatment process should be considered. In order to determine a reasonable temperature range for the pyrolysis of organic materials in dried films, we performed the thermogravimetric analysis (TGA, $10^{\circ} \mathrm{C} \mathrm{min}^{-1}$ in air) for the lanthanum nitrate $\left[\mathrm{La}\left(\mathrm{NO}_{3}\right)_{3} \cdot 6 \mathrm{H}_{2} \mathrm{O}\right]$, nickel acetate $\left[\mathrm{Ni}\left(\mathrm{CH}_{3} \mathrm{COO}\right)_{3} \cdot 4 \mathrm{H}_{2} \mathrm{O}\right]$ and $\mathrm{LaNiO}_{3}$ gel, respectively. Figure 1 illustrates thermogravimetric analysis (TGA) curves for lanthanum nitrate $\left[\mathrm{La}\left(\mathrm{NO}_{3}\right)_{3} \cdot 6 \mathrm{H}_{2} \mathrm{O}\right]$, nickel acetate $\left[\mathrm{Ni}\left(\mathrm{CH}_{3} \mathrm{COO}\right)_{3} \cdot 4 \mathrm{H}_{2} \mathrm{O}\right]$ and the gel obtained from the LNO precursor solution after evaporation of acetic acid solvent at $120^{\circ} \mathrm{C}$ for $8 \mathrm{~h}$. The TG curve of $\mathrm{La}\left(\mathrm{NO}_{3}\right)_{3} \cdot 6 \mathrm{H}_{2} \mathrm{O}$ indicates a multi-step weight-loss process: below $345^{\circ} \mathrm{C}$ is the process of stepwise loss of crystallized water to form anhydrous $\mathrm{La}\left(\mathrm{NO}_{3}\right)_{3}\left(75.48 \%, 342^{\circ} \mathrm{C}\right.$; calculated: $75 \cdot 04 \%$ ), followed by the decomposition of $\mathrm{La}\left(\mathrm{NO}_{3}\right)_{3}$ to $\mathrm{La}_{2} \mathrm{O}_{3}\left(38.01 \%, 624^{\circ} \mathrm{C}\right.$; calculated: $\left.37.62 \%\right)$ in the range of $340-625^{\circ} \mathrm{C}$, which is similar basically to the earlier reports (Gao et al 1988). For $\left[\mathrm{Ni}\left(\mathrm{CH}_{3} \mathrm{COO}\right)_{3} \cdot 4 \mathrm{H}_{2} \mathrm{O}\right]$ a relatively simple $\mathrm{TG}$ curve was observed, where the weight loss between 100 and $120^{\circ} \mathrm{C}$ is generally the release and evaporation of crystallized water (71.23\%, $124^{\circ} \mathrm{C}$; calculated: $71.04 \%$ ), and then the evolution and decomposition of acetic acid between 120 and $350^{\circ} \mathrm{C}$ with the product of $\mathrm{NiO}$ and $\mathrm{Ni}$ which is finally oxidized to $\mathrm{NiO}\left(27.95 \%, 634^{\circ} \mathrm{C}\right.$; calculated: $\left.30.01 \%\right)$ between 350 and $600^{\circ} \mathrm{C}$, as observed by Elmasry et al (1996). For the $\mathrm{LaNiO}_{3}$ precursor gel, the weight loss below $150^{\circ} \mathrm{C}$ is due to the loss of residual acetic acid in the precursor gel and the partial loss of crystallized water in the two precursors. The dehydration step of two precursor materials occurs mainly between 150 and $350^{\circ} \mathrm{C}$ to form individual metal oxides $\left(36.36 \%, 681^{\circ} \mathrm{C}\right.$; calculated: $\left.36.02 \%\right)$. The TGA curve of decomposition of the mixed salts is the overlap of the TG curves for the separate salts, but the decomposition reactions are shifted to lower temperatures,

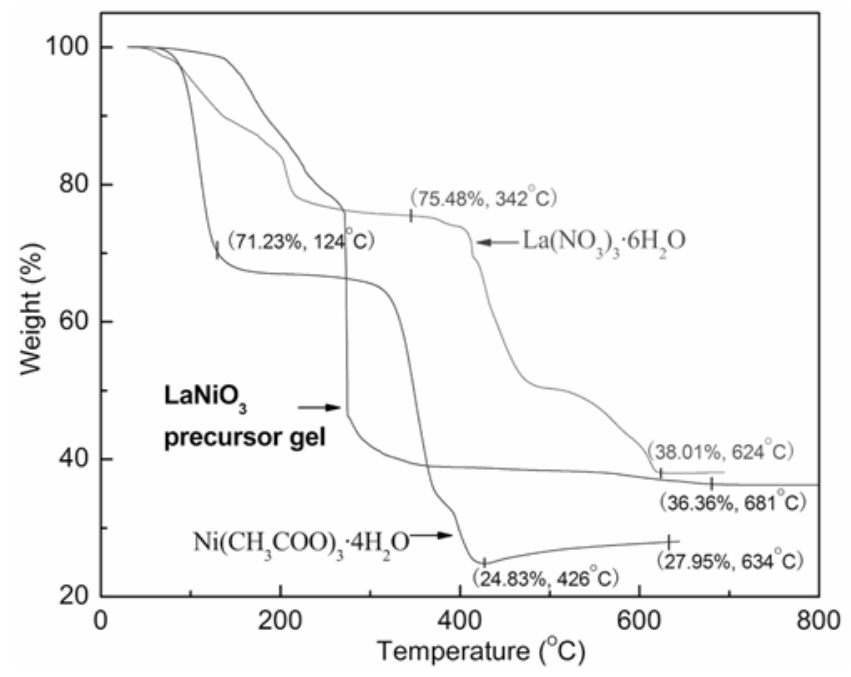

Figure 1. Thermal analysis of $\mathrm{La}\left(\mathrm{NO}_{3}\right)_{3} \cdot 6 \mathrm{H}_{2} \mathrm{O}, \mathrm{Ni}\left(\mathrm{CH}_{3} \mathrm{COO}\right)_{2}$. $4 \mathrm{H}_{2} \mathrm{O}$ and $\mathrm{LaNiO}_{3}$ precursor gel. 
similar to thermal decomposition behaviors of the mixture of $\mathrm{Ni}(\mathrm{II})$ and $\mathrm{Fe}(\mathrm{III})$ acetates (Elmasry et al 1996). Based on the TGA curves we selected the initial pyrolysis temperature for $\mathrm{MOD}-\mathrm{LaNiO}_{3}$ just above $300^{\circ} \mathrm{C}$.

We have chosen two heat treatment temperature points to investigate the decomposition and phase formation in the $\mathrm{LaNiO}_{3}$ precursor gels. Figure 2 gives XRD patterns of the powders treated at 400 and $700^{\circ} \mathrm{C}$ for $3 \mathrm{~h}$ in air. The sample after firing at $400^{\circ} \mathrm{C}$ for $3 \mathrm{~h}$ displayed several broad diffraction peaks that could be assigned to those of $\mathrm{La}_{2} \mathrm{O}_{3}, \mathrm{NiO}, \mathrm{Ni}_{2} \mathrm{O}_{3}$ or $\mathrm{LaNiO}_{3}$ phases. It could be said that the precursor gel completely decomposed into the metal oxides together with a little amount of the $\mathrm{LaNiO}_{3}$ phase at $400^{\circ} \mathrm{C}$. Compared to the results of the thermal analysis above, it is found that the decomposition temperature of $\mathrm{LaNiO}_{3}$ gel is indeed lower than that of each precursor material. With increasing heat treatment temperature up to $700^{\circ} \mathrm{C}$, the $\mathrm{XRD}$ reflections indexed well according to the $\mathrm{LaNiO}_{3}$ phase. It means that the $\mathrm{LaNiO}_{3}$ gel was completely crystallized up to $700^{\circ} \mathrm{C}$. The detailed investigation of heat treatments on orientation of MODfilms will be discussed later.

Now we discuss the $\mathrm{LaNiO}_{3}$ films by MOD with different low-temperature heat treatments between 300 and $450^{\circ} \mathrm{C}$, i.e. just higher than the determined initial pyrolysis temperature by TGA technique. The treatment temperature of phase formation is fixed at $700^{\circ} \mathrm{C}$. In figure 3 the XRD patterns are plotted for four samples. Only (h00)-oriented peaks of the $\mathrm{LaNiO}_{3}$ phase are observed except for the sample heat-treated at $450^{\circ} \mathrm{C}$. The temperature dependence of the (200) peak on the low-temperature heat treatment is shown in the inset of figure 3. The strongest (200) reflection intensity was detected for the sample treated at $350^{\circ} \mathrm{C}$. The degree of preferred

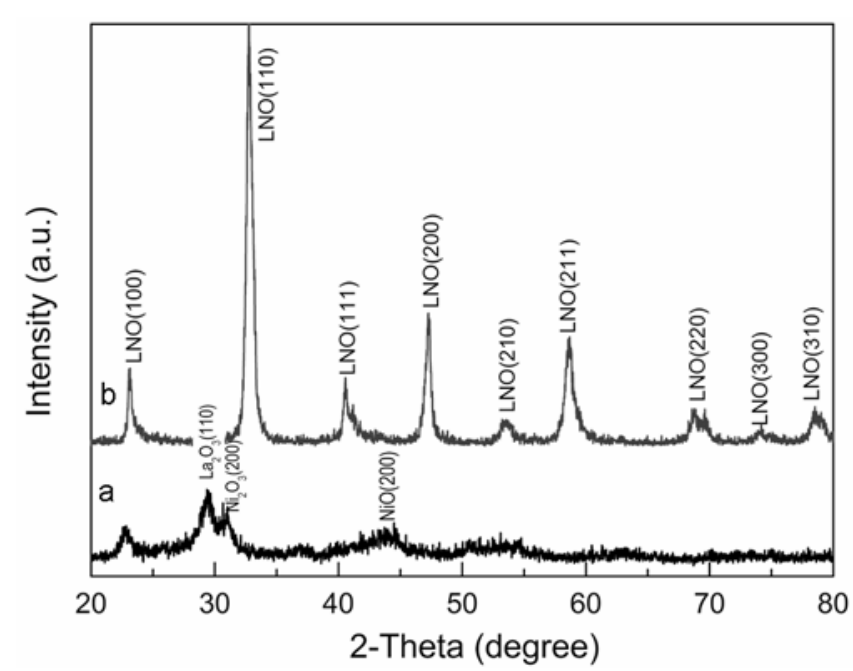

Figure 2. XRD patterns of the powder derived from the $\mathrm{LaNiO}_{3}$ gel after heat treatments at (a) $400^{\circ} \mathrm{C}$ and (b) $700^{\circ} \mathrm{C}$ for $3 \mathrm{~h}$ in air. orientation $F$ (Lotering 1959), first proposed by Lotering, was employed to estimate the film texture here. The $F$ value was found to be close to 0.90 for the sample treated at $350^{\circ} \mathrm{C}$ ) (see the inset of figure 3 ). This indicates that lower or higher heat treatments are destructive for the (h00)-oriented films. The heat treatment at lower temperature may result in incomplete decomposition of the $\mathrm{LaNiO}_{3}$ gels, whereas the heat treatment at higher temperature could lead to non-simultaneous pyrolysis of components in the gels. These two heat treatment profiles are unfavourable for nucleation of oriented $\mathrm{LaNiO}_{3}$ crystallites.

Figure 4 displays the effect of annealing temperature on the $\mathrm{LaNiO}_{3}$ film texture prepared by MOD. All samples were heat-treated at $350^{\circ} \mathrm{C}$ for $2 \mathrm{~h}$ in air. The annealing step was carried out at various peak temperatures of $T=500-800^{\circ} \mathrm{C}$ for $3 \mathrm{~h}$ in a horizontal furnace. When the annealing temperature is lower than $800^{\circ} \mathrm{C}$, the $(h 00)$ peaks of $\mathrm{LaNiO}_{3}$ are observed. The strongest (200) reflection occurs for the sample treated at $600^{\circ} \mathrm{C}$. At the same time the $F$ value reaches a maximum. However, the film annealed at $800^{\circ} \mathrm{C}$ shows an unknown diffraction peak, which may be due to the decomposition of the $\mathrm{LaNiO}_{3}$ phase (Cho et al 1997).

In order to investigate the effect of film thickness on the film texture, we prepared $\mathrm{LaNiO}_{3}$ films by multicoating technique. The precursor film with a single spin coating was first fired at $350^{\circ} \mathrm{C}$ for $1 \mathrm{~h}$ to remove organic components, and then the spin coating was repeated, followed by pyrolysis again at $350^{\circ} \mathrm{C}$. This process was repeated several times to achieve desired film thickness from $30 \mathrm{~nm}$ to $150 \mathrm{~nm}$. Finally, the fired films were heated at $700^{\circ} \mathrm{C}$ for $3 \mathrm{~h}$ for crystallization. Figure 5 gives XRD patterns of different thick films. It is found that the LNO ( $h 00)$ peaks are dominant in all three different

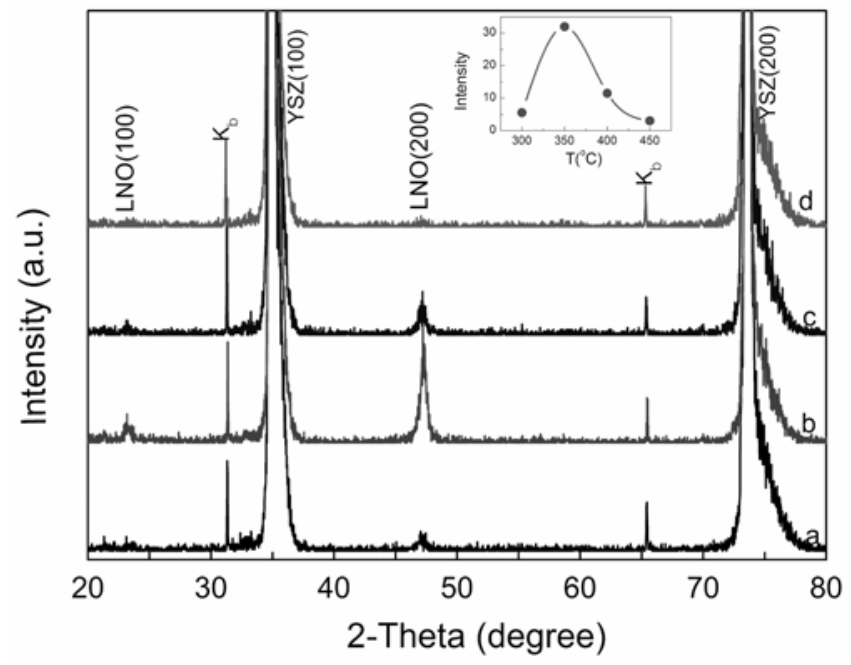

Figure 3. XRD profiles of $\mathrm{LaNiO}_{3}$ films YSZ (100) heattreated at (a) $300^{\circ} \mathrm{C}$; (b) $350^{\circ} \mathrm{C}$; (c) $400^{\circ} \mathrm{C}$ and (d) $450^{\circ} \mathrm{C}$ for $3 \mathrm{~h}$, then annealed at $700^{\circ} \mathrm{C}$ for $1 \mathrm{~h}$ in air. 
thickness films. However, the thickest film of about $150 \mathrm{~nm}$ (five times coating) shows not only the LNO (h00) peaks but also the LNO (110) peak. This suggests that the degree of the $c$-axis texture decreases when the thickness of $\mathrm{LaNiO}_{3}$ film is too high. Good (h00) orientation of $\mathrm{LaNiO}_{3}$ films can be obtained if the film thickness is not greater than about $100 \mathrm{~nm}$. If we consider a relatively large lattice mismatch of $5.5 \%$ between $\mathrm{LaNiO}_{3}$ and YSZ, the $(h 00)$ orientation of $\mathrm{LaNiO}_{3}$ films might gradually become weak with increasing the film thickness because of possible strain relaxation.

AFM investigations of surface morphology of the $\mathrm{LaNiO}_{3}$ films were carried out and the AFM images are illustrated in figure 6. All images show no cracks and no

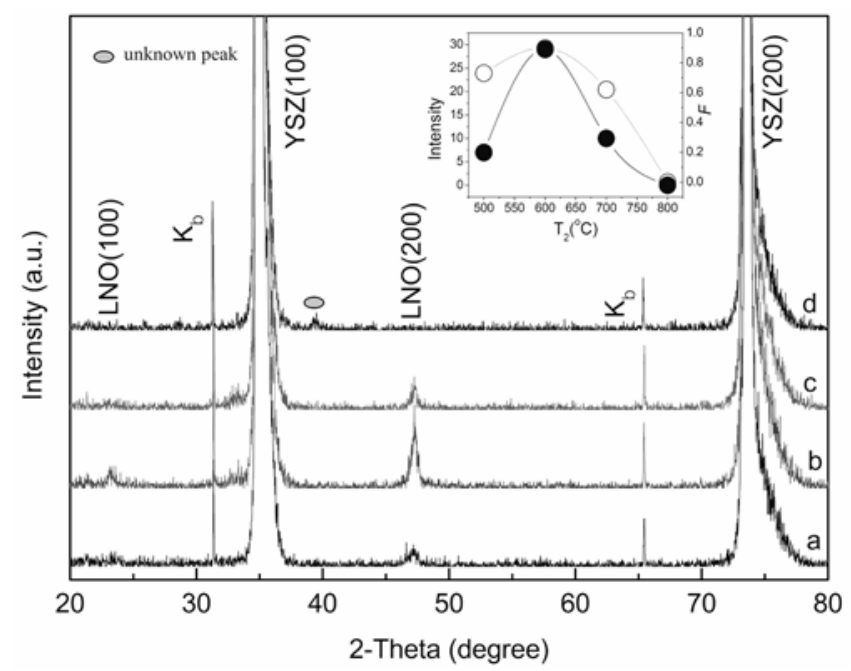

Figure 4. XRD profiles of $\mathrm{LaNiO}_{3}$ films on YSZ (100) substrates initially heat-treated at $350^{\circ} \mathrm{C}$ for $2 \mathrm{~h}$ then annealed at (a) $500^{\circ} \mathrm{C}$; (b) $600^{\circ} \mathrm{C}$; (c) $700^{\circ} \mathrm{C}$ and (d) $800^{\circ} \mathrm{C}$ for $3 \mathrm{~h}$ in air.

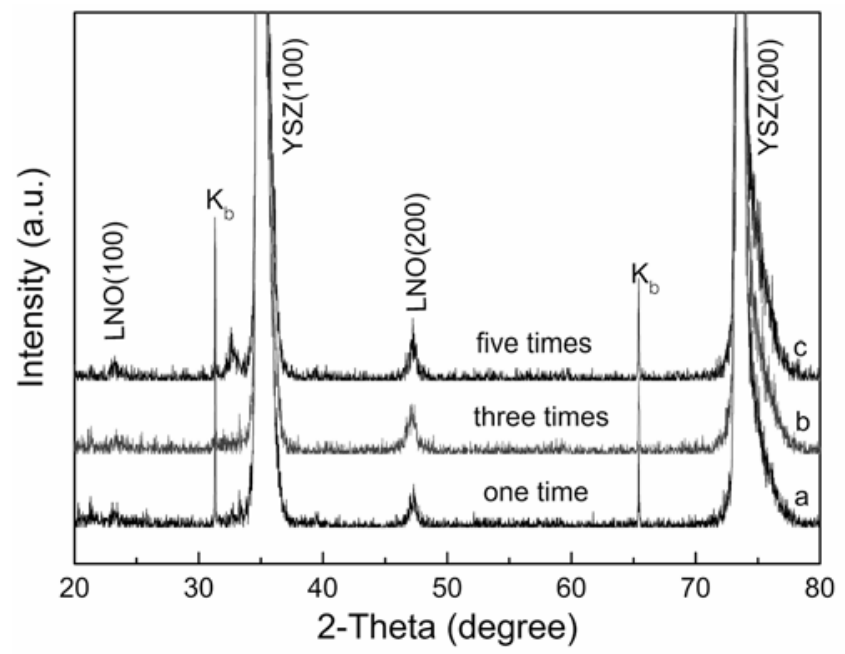

Figure 5. XRD patterns of $\mathrm{LaNiO}_{3}$ films on YSZ (100) with multi-coatings annealed at $700^{\circ} \mathrm{C}$ after pyrolysis at $350^{\circ} \mathrm{C}$. pinholes; the LNO surfaces comprise of densely packed round-shaped grains. The surface roughness is about $13 \mathrm{~nm}$ for the LNO film heat-treated at $700^{\circ} \mathrm{C}$ for $3 \mathrm{~h}$
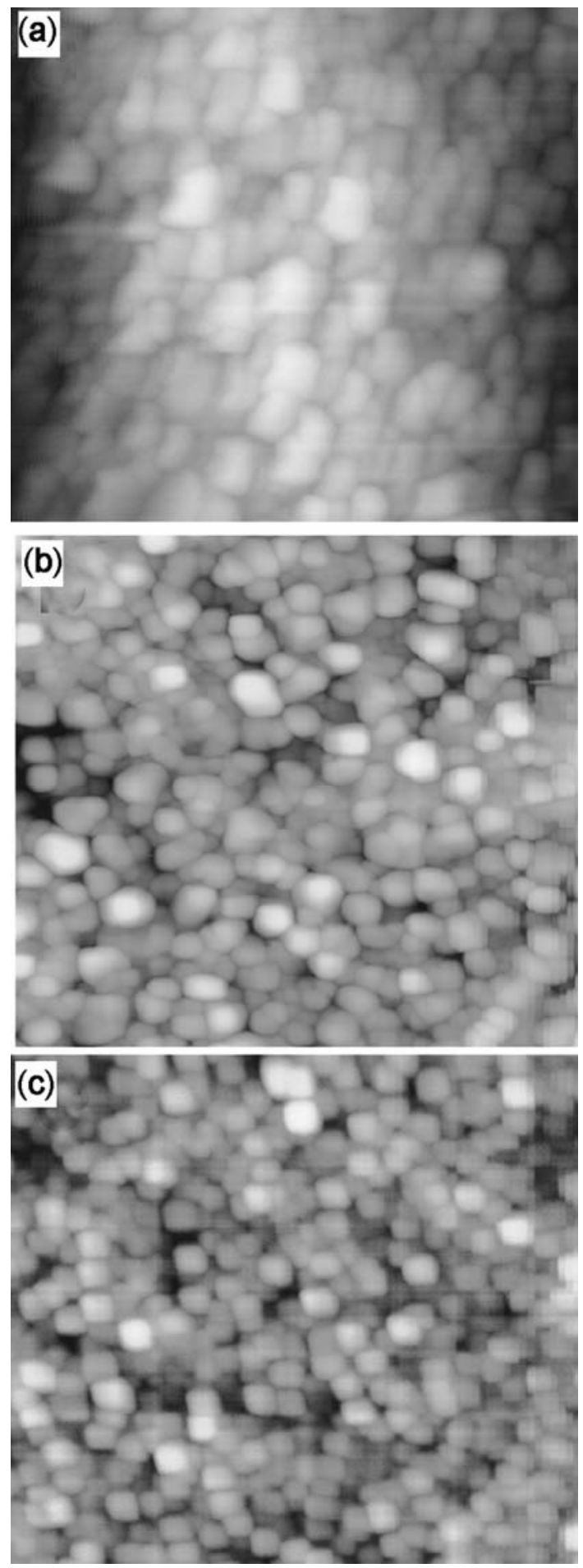

Figure 6. AFM images of LNO films on YSZ (100) substrate with different heat treatments. (a) Annealed at $700^{\circ} \mathrm{C}$ for $3 \mathrm{~h}$ without low-temperature heat treatment; (b) heat-treated at $350^{\circ} \mathrm{C}$ for $2 \mathrm{~h}$ and then annealed at $700^{\circ} \mathrm{C}$ for $3 \mathrm{~h}$ and (c) heattreated at $350^{\circ} \mathrm{C}$ for $2 \mathrm{~h}$ and then annealed at $600^{\circ} \mathrm{C}$ for $3 \mathrm{~h}$. 


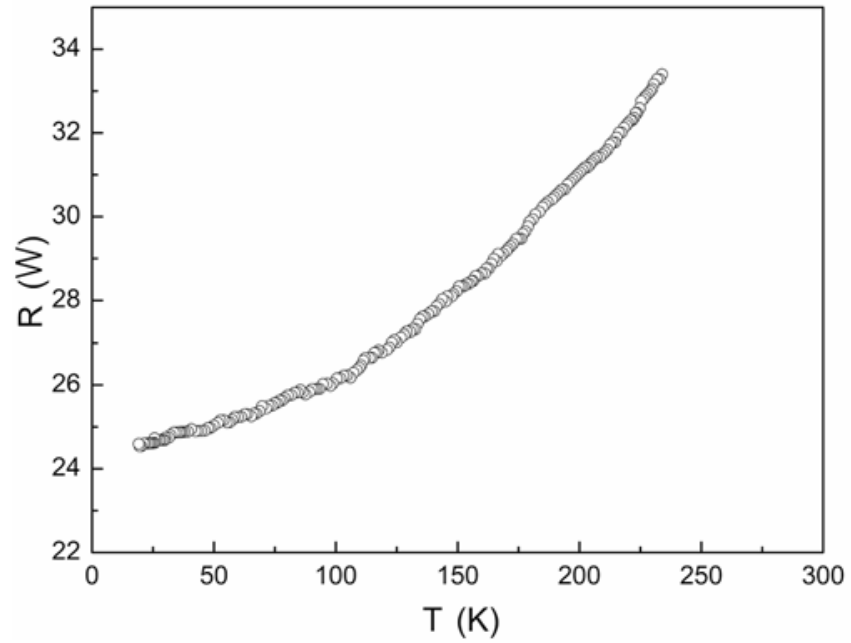

Figure 7. Typical temperature dependence of the electrical resistivity of $\mathrm{LaNiO}_{3}$ films.

without pyrolysis process (see figure 6a). When the LNO film experienced two-stage heat treatment of pyrolysis at $350^{\circ} \mathrm{C}$ for $2 \mathrm{~h}$ and then of annealing at $700^{\circ} \mathrm{C}$ for $3 \mathrm{~h}$, the surface roughness of the film decreases down to about $10 \mathrm{~nm}$ (see figure 6b). If the annealing temperature of $600^{\circ} \mathrm{C}$ is used, the surface roughness continues to decrease to $2.5 \mathrm{~nm}$ (see figure 6c). Such a low surface roughness of $\mathrm{LaNiO}_{3}$ films prepared via MOD is comparable with that of films by sputtering technique (Wakiya et al 2002).

In order to explore the conductivity of these $\mathrm{LaNiO}_{3}$ films, we have performed measurements of the electrical resistivity vs temperature as shown in figure 7 . The typical $R(T)$ curve displays a monotonic decrease of resistivity with decreasing temperature, which confirms a metallic behaviour like that found in the PVD films (Cho et al 1997).

\section{Conclusions}

In conclusion, the (h00)-orientated $\mathrm{LaNiO}_{3}$ films on YSZ (100) substrates were successfully fabricated by MOD with high-quality precursor solution. The orientation of $\mathrm{LaNiO}_{3}$ films is greatly influenced by heat treatment profiles at low and high temperatures, which is related to the processes of decomposition and crystallization. With increasing film thickness, the pure $(h 00)$ texture becomes more and more weak. Under optimal conditions, the smooth films of $\mathrm{LaNiO}_{3}$ with highly (h00) texture could be obtained. Therefore, the MOD-LaNiO 3 is a potential candidate for buffer layer of YBCO-coated conductors.

\section{Acknowledgements}

This work was financially supported by the National 863 Program of China (Grant No. 2006AA03Z204).

\section{References}

Bao D, Yao X, Wakiya N, Shinozaki K and Mizutani N 2003 J. Phys. D. Appl. Phys. 361217

Berini B, Noun W, Dumont Y, Popova E and Keller N 2007 J. Appl. Phys. 101023529

Bhuiyan M S, Paranthaman M and Salama K 2006 Supercond. Sci. Technol. $19 \mathrm{R} 1$

Cho C R, Payne D A and Cho S L 1997 Appl. Phys. Lett. 71 3013

Elmasry M A A, Gaber A and Khater E M H 1996 J. Therm. Anal. Calor. 47757

Escote M T, Pontes F M, Leite E R, Varela J A, Jardim R F and Longo E 2003 Thin Solid Films 44554

Gao S Z and Yang B 1988 Z. Xibei Jianzhu Gongcheng Xueyuan Yuanbao 265

Huang H, Yao X, Wang M and Wu X 2004 J. Cryst. Growth 263406

Knoth K, Hühne R, Oswald S, Schultz L and Holzapfel B 2007 Acta Mater. $\mathbf{5 5} 517$

Larbalestier D, Gurevich A, Feldmann D M and Polyanskii A 2001 Nature 414368

Lee J, Johnson L, Safari A, Ramesh R, Sands T, Gilchrist H and Keramidas V G 1993 Appl. Phys. Lett. 6327

Li A, Ge C, Lü P and Ming N 1996a Appl. Phys. Lett. 68 1347

Li A, Ge C, Lü P and Ming N 1996b Appl. Phys. Lett. 70 1616

Lotering F K 1959 J. Inorg. Nucl. Chem. 9113

Meng X J, Cheng J G, Sun J L, Ye H J, Guo S L and Chu J H 2000 J. Crystal Growth 220100

Miyake S, Yamamoto K, Fujihara S and Kimura T 2002 J. Am. Ceram. Soc. 85992

Miyazaki H, Goto T, Miwa Y, Ohno T, Suzuki H, Ota T and Takahashi M 2004 J. Eur. Ceram. Soc. 241005

Sanchez F, Ferrater C, Guerrero C, Garcia-Cuenca M V and Varela M 2000 Appl. Phys. A71 59

Wakiya N, Azuma T, Shinozaki K and Mizutani N 2002 Thin Solid Films 41014

Yu S, Yao K and Tay Eng Hock F 2004 Ceram. Int. 301253

Zhang Y, Zhou QF, Chan H L W and Choy C L 2000 Thin Solid Films 37587 